\title{
Complete pathological response of NSCLC
}

\author{
${\text { K Kovács }{ }^{1 *}, \text { C Oláh }^{1}, \text { G Cserni }{ }^{2}, \text { R Vizhányó }}^{3}$, JP Szekeres ${ }^{1}$ \\ From 23rd World Congress of the World Society of Cardio-Thoracic Surgeons \\ Split, Croatia. 12-15 September 2013
}

\section{Background}

In the last ten years we have operated 35 patients after induction chemotherapy. We would like to present two cases of a pCR of a NSCLC.

\section{Methods}

In a $64 y$ o. male a squamous cell lung cancer was diagnosed in his left upper lobe by bronchoscopic brush biopsy cytology. Stage III.A cT2N2MO. He underwent the neoadjuvant treatment: received six cycles of cisplatin etoposid combination. After the restaging (Stage IBycT2NOMO) we performed a pneumonectomy and the mediastinal blockdissection, because of the involvement of the pulmonary artery and spreading to the lower lobe. The pathologist found only pulmonary fibrosis, but no tumor. In 50 y.o. male an adenocarcinoma of the right upper lobe was diagnosed by bronchoscopic brush cytology. Stage IIIA cT3N2MO. He received the same induction therapy regimen. After restaging (Stage IBycT2NOMO) he underwent a right upper lobectomy. At the operation we have not found any abnormal or enlarged N2 lymphonodes. The hystopathological examination showed only necrotic tissues and haemorrhages, but no tumour. Both patients are alive without any complications and tumourfree.

\section{Conclusions}

As a result of the collaboration with the other pulmonology departments we operate more and more lung cancer patients after neoadjuvant treatment. We can achieve an improvement in the operability and can perform organ-preserving resections as well with the multimodality therapy. In the future we need a special diagnostic method helping in the decision to not perform a resection at all.

\footnotetext{
* Correspondence: kovacskaroly@hotmail.com

'Department of Surgery, Bács-Kiskun County Teaching Hospital Kecskemét, Hungary

Full list of author information is available at the end of the article
}

Authors' details

${ }^{1}$ Department of Surgery, Bács-Kiskun County Teaching Hospital Kecskemét, Hungary. ${ }^{2}$ Depertment of Pathology, Bács-Kiskun County Teaching Hospital Kecskemét, Hungary. ${ }^{3}$ Department of Oncology, Bács-Kiskun County Teaching Hospital, Kecskemét, Hungary.

Published: 11 September 2013

doi:10.1186/1749-8090-8-S1-O227

Cite this article as: Kovács et al:: Complete pathological response of NSCLC. Journal of Cardiothoracic Surgery 2013 8(Suppl 1):O227.

\section{Submit your next manuscript to BioMed Central and take full advantage of: \\ - Convenient online submission \\ - Thorough peer review \\ - No space constraints or color figure charges \\ - Immediate publication on acceptance \\ - Inclusion in PubMed, CAS, Scopus and Google Scholar \\ - Research which is freely available for redistribution \\ Submit your manuscript at www.biomedcentral.com/submit}

C Biomed Central

C 2013 Kovács et al; licensee BioMed Central Ltd. This is an Open Access article distributed under the terms of the Creative Commons Attribution License (http://creativecommons.org/licenses/by/2.0), which permits unrestricted use, distribution, and reproduction in any medium, provided the original work is properly cited. 